\title{
Preparation of pellets from uranium dioxide without binder
}

\author{
M.P.Odeychuk, S.A.Sirenko \\ NSC "Kharkiv Institute of Physics and Technology", \\ 1 Akademicheskaya Str., 61108 Kharkiv, Ukraine
}

Received April 14, 2014

\begin{abstract}
In the article the considered method of making of fuel pellets is from $\mathrm{UO}_{2}$ without connective. This method allows to make fuel pellets with enhanceable technico-operating by descriptions.
\end{abstract}

Рассмотрен метод изготовления топливных таблеток из $\mathrm{UO}_{2}$ без связующего. Данный метод позволяет изготовлять топливные таблетки с повышенными технико-эксплуатационными характеристиками.

\begin{abstract}
Дослідження удосконаленого процеса виготовлення таблеток з діоксиду урану. М.П.Одейчук, С.А.Сіренко.

Розглянутий метод виготовлення паливних таблеток з $\mathrm{UO}_{2}$ без єднального. Даний метод дозволяє виготовляти паливні таблетки з підвищеними техніко-експлуатаційними характеристиками.
\end{abstract}

\section{Introduction}

Development of fuel elements on highburning and hence lengthening campaign involves solving many problems. On the modern stage of nuclear energy development the problem of improvement the technical and operational characteristics is urgent for the fuel elements based on pellets fuels. Therefore much attention is given to improving of preparation technology of $\mathrm{UO}_{2}$ pellets.

Currently, uranium dioxide is the main kind of nuclear fuel for nuclear power reactors on the water. The scale of production of uranium dioxide powder of low enrichment and pellets on its basis is very large and for the needs of Ukrainian Nuclear Power Plants it requires about 100 million pellets per year. In spite of such huge scale of production all pellets must have practically identical or very little different from each other operational characteristics [1].

Technological schemes of mass production of pellets have been developed with taking into account of the complex of severe requirements that follow from the condition to ensure reliable operation of nuclear power reactors and low cost of generated electricity.

Pressing is the most important stage in pellet preparation. In the process of pressing the main characteristics of the tablets are following: form, geometric sizes, strength, density and uniformity of its distribution over the whole volume of pellet.

Pressing process should provide:

- the required form of pellets;

- hard dimensional tolerances for the diameter of the pellet $( \pm 0.01 \mathrm{~mm})$ and for its height $( \pm 1.0 \mathrm{~mm})$;

- required density and uniformity of its distribution over the whole volume of pellet. According to the modern requirements the density of pressings should be not less than (56-57) \% TD and it scatter should be no more than $1.5 \%$ TD; the effort of pellet fracture (strength) should be not less than 8.3 MPa. 
One of the most important characteristics of fuel is density of sintered pellets, the value of which depends from the physicochemical properties of the original uranium dioxide powders and from used sintering processes of pellets.

In the last decade in many countries the method of "dry" pressing of the pellets has being worked intensively [2]. For realization of such method there are required the powders which are able to fill the press-mold without additional impact. For today uranium dioxide powders which obtained in AUC (trikarbonatouranilat) and IDR (poliuranat ammonium)-processes best meet of such requirements [3].

The process of the powder preparation for pressing, in particular with the use of liquid binders, is time-consuming and significantly complicates the technology of pellet manufacturing. At present it is being developed as a new way to obtain of nuclear fuels and so improvement of existing technology [2].

In order to improve the press-ability of the powder, reduce the pressing and ejecting forces and reduce the press tool wear some binders and lubricant agents are used, which in the form of solution or dry powder are introduced into the charge before pressing or the working part of the press-molds can be coated by the lubricant.

Pressing with binder and with lubricant is made from $\mathrm{UO}_{2}$ granulated powder and it is the basic kind of fuel pellets formation, developed in Russia.

When producing of pellets by pressing with hard dimensional tolerances is necessary to consider the effect of the elastic aftereffect, which arises as a result of internal stresses. Especially it is important to consider for diameter of pellets in connection with the small dimensional tolerances on it.

In the process of pushing out of pellet from the press-mold tensile longitudinal stresses and compressive transverse stresses are gradually removed, but additionally shear stresses may occur. For example, in the moment of releasing from the pressmold, its upper part is released in the first place and is experiencing the transverse expansion, while the rest of pellet is still in press-mold, which may cause separation (offset) of overpress part of pellet from compressed part of pellet or may lead to crack formation [4].

Pressing without binder - "dry" pressing - is carried out without introduction into the charge any binders and lubricants. For pressing without binder it is needed $\mathrm{UO}_{2}$ powder with half dendrite structure. $\mathrm{UO}_{2}$ powders, obtained by AUC-process, have such structure and they are pressed without additional pretreatment. Such powders are sufficiently technologic, because they have good flow ability and high bulk density. The powders, obtained by IDR-process are also pressed without introduction of binder, but with pretreatment - dry granulation for enhance the fluidity.

In recent times pellet manufacturers pay great attention on removing of sharp edges of pellets. This is because the sharp edge in manufacturing leads to an increased yield of defective goods under grinding operation and under the overloading, because it is the most vulnerable to chipping. When filling the fuel element sharp edge may crumble and this leads to discontinuity of the fuel rod.

Preparation of pellets without sharp edge has a number of advantages: defective goods for chipping and formation of chips during outfit process and technological interoperational transportation are reduced, number of lockups pellets at removal of cladding from the fuel elements are decreased. Bulk weight of powders by AUCprocess and IDR-process were respectively $2.6 \mathrm{~g} / \mathrm{cm}^{3}$ and $2.7 \mathrm{~g} / \mathrm{cm}^{3}$.

In our ongoing investigations the starting material for the preparation of pellets was $\mathrm{UO}_{2}$ powder obtained by the ADU-process.

For pressing without binder presses with automatic lubrication of press-molds were developed. Lubricant on the basis of spindle oil is applied to uniform layer to the surface of punches and matrixes in order to reduce ejection pressure and obtaining of the quality compacts.

From discussed methods of manufacture of pellets the most promising and less labor intensive is method of manufacturing pellets without binder by method of "dry" pressing. The main advantage is reduction of productive cycle of pellets manufacturing. Such labor intensive and lengthy operations as the dosing of binder substances and its mixing with the powder, drying and outgassing of pellets are excluded. Quality of the finished tablets is improved (density is increased, variation in the size of the outer diameter is reduced, possible of grinding operation is excepted, the carbon content is reduced to 0.01 wt. $\%$ ) [5]. 


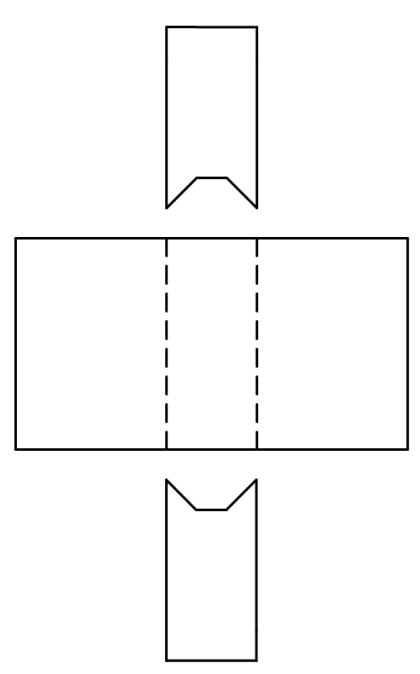

Fig. 1. The design of press-mold.

\section{Experimental}

Investigation on development of operations and regimes of oxide fuel fabrication was carried out using of uranium dioxide powder with size particle of (10-15) $\mu \mathrm{m}$.

Realization of the above requirements for qualitative and quantitative parameters of the fuel pellets from uranium dioxide is difficult task, because the parameters of the pellet has among themselves a certain relationship, and change of one of them leads to change in another.

For performing of works on creation of fuel with high technical characteristics the complex of measures on the improvement of the applied equipment was conducted. High temperature press-molds from molybdenum were designed and manufactured (Fig. 1).

The upper and lower punches are made with cutouts under chamfer of the pellet. $\mathrm{UO}_{2}$ powder (without binder) was backfilled into the press-mold in the free-backfill condition. Pressing was carried out on the hydraulic press P6320. The pressing pressure was $3000 \mathrm{kgf} / \mathrm{cm}^{2}$. After that pressed pellets without removing together with pressmold was passed on the sintering stage in high-temperature furnace with a graphite heater which was made on the basis of the vacuum unit VUM-10. The sintering process

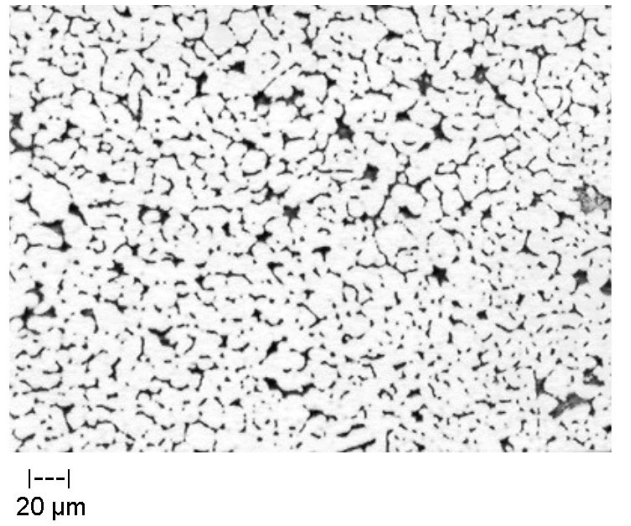

Fig. 2. Optical picture of uranium dioxide surface.

was carried out in vacuum $13.3 \cdot 10^{-2} \mathrm{~Pa}$ at the temperature of $1750^{\circ} \mathrm{C}$ during $1 \mathrm{~h}$.

\section{Results and discussion}

Compacted and final sintered $\mathrm{UO}_{2}$ pellets had flat, smooth without cracking and chipping surface.

In serial production of $\mathrm{UO}_{2}$ pellets by compression in the molding forms it is very important to obtain good reproducibility of the density from the product to the product, which manufactured at the same compaction pressure. For other characteristics existing differences are insignificant (Table).

Strength of the sintered pellets is greater than the same values for the pellets manufactured according to the technology with a binder using.

The characteristic structure of the sintered pellets is presented in Fig. 2. The uniform structure is observed with visible inclusions and cracks with some share of pores.

Conducted researches have shown that the main characteristics of pellets prepared by pressing without binder, not practically differ from the properties of pellets obtained by traditional technology. In the 80 years requirements on density for conditional pellets were $(10.6-10.8) \mathrm{g} / \mathrm{cm}^{3}$. At present, in connection with the lengthening of campaign and increasing of nuclear fuel

Table. Characteristics of $\mathrm{UO}_{2}$ pellets of experimental batch fabricated without binder and with using binder

\begin{tabular}{||c|c|c||}
\hline Parameters & Pressing without binder & Pressing with binder \\
\hline Density of the sintered pellets & $\mathrm{g} / \mathrm{cm}^{3}$ & 10.50 \\
Strength of sintered pellets & $\mathrm{kg} / \mathrm{cm}^{2}$ & 30 \\
Pellet diameter shrinkage during sintering , \% & $\mathbf{1 5 . 5 - 1 6 . 5}$ & $\mathbf{1 4 . 8 - 1 5 . 2}$ \\
\hline
\end{tabular}


burn-up the requirements on density for pellet fuel was reduced to (10.410.6) $\mathrm{g} / \mathrm{cm}^{3}$. As seen from Table the pellets which prepared by the proposed method are compliance with this requirement. To move to the full-scale production of nuclear fuel which produced by pressing without binder will still require additional researches for substantiating of its operability.

\section{Conclusions}

The sintered pellets fabricated by pressing without binder are corresponding to the modern requirements for pellet fuel for nuclear reactor.

Preparation of the pellets from uranium dioxide without binder significantly simplifies of the technology without reducing quality of the products: no need the operations for the binder removal.

Chemical purity is higher in the pellets fabricated by pressing without binder than the pellets which prepared by the tradi- tional technology, due to lack of lubricants reagent and binder additives.

Percentage of cracks formation is reduced due to the influence of the elastic aftereffect arising as a result of the internal stresses action which arises in the pellet ejection process from the press-mold.

\section{References}

1. V.Khefli, Problemy and Prospects of Nuclear Energy. Announcer AN USSR, No.12, ???? (1990).

2. V.Makhova, Yu.V.Smirnov, A.D.Sokolova et al., Vodo-vodyanye Reactors and their Fuel Cycle Abroad, Vyp. 18, Improvement of Fuel of Vodo-vodyanykh Reactors, Review, Energoatomizdat, Moscow (1995).

3. G.E.Somayajulu, in: Proc. Symp. on Improvements in Water Reactor Fuel Technology and Utilization, Stockholm, Sweden 1986, IAEA, Vienna 1987, p.493.

4. A.M.Umanskiy, Pressovanie Powder-like Materials, Metallurgy, Moscow (1981) [in Russian].

5. D.Franklin et al., Advances in Light Water Reactor Fuels. - Trans. ANS, 55, 255 (1987). 